\title{
English and Javanese used for learning automotive literacy in vocational schools
}

\author{
Sudar \\ Muhammadiyah University of Purworejo \\ Purworejo, Indonesia \\ rofiqsdr@gmail.com
}

\begin{abstract}
The aims of this paper is to investigate the using of language used by students of vocational schools. The researcher is interested to know language used by students of vocational schools when they were learning the components and engines of light vehicles. The researchers assumed that the language used by them are English and Javanese. Why it is English? The researcher investigated that most of the components and the engines of light vehicles used English for naming that components and engines. Secondly, the language used by students of vocational school is Javanese. It is the fact that mostly the teachers and students of vocational schools are Javanese speakers. To investigate the data, analyzed the data, and to interpret the data, the researcher used the Miles Hubarman (1996) technique of data analysis. Further, this study is used qualitative descriptive study. Based on the results of data analysis, it is stated in the graphic that students of vocational school in Purworejo used English and Javanese for learning the components and the engines of light vehicles.
\end{abstract}

Key words: English, Javanese, automotive, literacy, vocational school

\section{Introduction}

Literacy is human being need. Any people around the world should be literate. Literacy is basic competence for any people. Having a good literacy any ones is able to develop their competence to covers any needs that they want to get. Literacy is commonly not only in one of life-side, literacy can be in any fields of human activities. Kern, (2000) literacy can be about family literacy, computer literacy, science literacy, visual literacy, economic literacy, geographic literacy, TV literacy, junk food literacy, label literacy, religious literacy, and cultural literacy. Based on this idea, the writer argues that there are still any other sides of literacy. In this article, I discuss particularly focuses on engineering. It is about automotive literacy. To understand well the philosophy of literacy itself, the writer starts to discuss the term literacy form root description. Hammond (1992) states that literacy is the ability to read, write and spell correctly. Traditionally, the teaching literacy is skill based where it focuses on speech written down. Further, Kern, (2000) states that literacy involves the ability to recognize and produce graphic representation of words and morphemes. Based on this idea, the writer describe in this article about how did the students to be literate knowing the automotive terms in learning engineering. Talking about literacy is necessary for us as educated people, it is because by learning literacy we are able to communicate to other people from diversity countries around the worlds. Now, we are in the era of globalization, it means that it is very possible one should understand and able to use more than one languages. It is demanded because there are many activities conducted both in national and International community using English is not avoided. Learning engineering in the vocational schools is possible use local language as a means of communication. This article focuses the language use by students in the local setting, even the language used in the automotive tools and vehicle is English. It is a fact, the writer assumes that the language used by students in learning engineering is English and also Javanese.

Bill Cope and Kalantzis (2000), argue that culture and linguistics diversity is now as a central and critical issue. It meant that using more than one languages is included the literacy discussion which is necessary to be learned by any people in their life. Further, Kalantzis (2000) describes that language, discourse, register differences are makers of life world differences. Globalization makes the economic changes, actually it is not only economic but also language changes. Lass and Urey (1994) cited in Kantzis, (2000) describes that cultural globalization can be seen to include a globalization of language practices. Owen and Schwinger, (2008) describe the philosophy 
of literacy differently, they state that literacy is the very heart of culture of quality and equality, for when people gain the power to decode their world. It is stated in the previous pages, literacy is can be in the any fields of life, this article focuses the literacy in term of engineering, particularly about the languages used by students when they are learning the tools and vehicles. Now, we are in the globalization era, it needs our life more demanded and competitively, further the society demanded grows globally and competitively. Engineers are becoming more complex. In the $21^{\text {st }}$ century the engineers should be more literate. White, Breslow, and Hasting (2015) mention there are four skills of engineers, they are critical thinking, problem solving, team work, and communication. Related this idea, to be literate is necessary for any people who want to success to communicate in the globalization era, it is included the engineers. The writer argues that the students of vocational engineering in Purworejo, central Java also should be literate, particularly the languages that they used for learning the tools and terms of vehicles. Ali, Hassan,Daud, and Jusoff, (2010) state that engineering is field that fast developing as a result of scientific and technological advancement. It meant that engineering is needed to be mastered well by any people in the level of knowledge and also in the level of technicians. Engineering terms should be mastered by technician, mechanics, and also scientist in relation to developing the knowledge. Further, Messer, Kelly, and Poirir (2005) explain that engineering education has for a long time propagated a narrow technical mindset no longer relevant to a world of community and globalization. Because this, lecturers, tutors, and students share goals, morals, values, attitudes, and behaviors from a local and global perspective. Messer, Kelly, and Poirir (2005) state that literacy is including the ability to use spoken and written language for a range of purposes and in different contexts such as the integrating speaking, listening, and critical thinking with reading, viewing, and writing across all subjects areas. Their discussion about literacy is more complicated, it meant that to be literate in terms of engineering for students of vocational schools is also needed in the globalization era. What languages did students use for learning tools and vehicles in learning engineering? This is particular discussion presented in this paper.

\section{Method}

Qualitative method is used in this study. It is qualitative field research. The researcher goes to the natural setting of conducting a research. This study uses the qualitative descriptive, it means that the researcher observing and explaining the social phenomenon happened in the society. Faisal, (1995:20) qualitative research informing the update issues so it is useful for technology and knowledge developments. Husein Umar (1999:81) descriptive research is used to collect, to interpret, to inquiry, and to analyzing the data.

The participants of this research are students of nine different vocational schools in Purworejo, Central Java, Indonesia. The nine different vocational schools are as follow; (1) state vocational school one Purworejo, (2) Taman Siswa vocational high school (3) Pembaharuan vocational school one, (4) Pembaharuan vocational school two, (5) Technological vocational school, (6) YPP vocational school, (7) Pancasila vocational school, (8) Indonesia Institute vocational school, and (9) Nurussalaf vocational school of Purworejo. The material of this research is utterances made by vocational school about inside and outside components light vehicles.

To collect the data the researcher conducted an observation and in-depth interview. (Chaedar, (2002: 154-156). Observation is a systematic analysis about phenomenon and behavior in the society of field research, while in-depth-interview is data collected which based on the dialogue between researcher and informants. To decide a good informant, the researcher should be considered to the following components; (a) accuracy and validity (b) the number of the informants, and (c) the authority of the researcher.

To analyze the data, the researcher conduct the following steps; (a) gathering the information through an interview, giving questionnaires, and direct observation, (b) reduction of the information valid and invalid data, (c) presenting the data both in form of tables and explanation, (d) taking a conclusion (Miles and Huberman, 1994: 18)

\section{Discussion}

The researcher describes the results of study based on the data analysis taken from the research subjects, they are students of nine different vocational high schools. The data taken from the field of the research by answering questionnaires. The questionnaires are about the process of using languages in vocational schools. The questionnaires are written based on the following research question: What are the languages used by students of vocational schools of Purworejo when they are learning the engines, tools, and components of vehicles? To answer this research question, the researcher describe the process of forming bilingualism by presenting the informants answer in the form of graphic. The graphic is the following;

Graphic of using languages in vocational schools Purworejo.

The graphic used quality of scale (Dornyei, 2010). The quality of scale are consisting: (1) never, (2) some time, (3) often, (4) mostly, (5) always. 


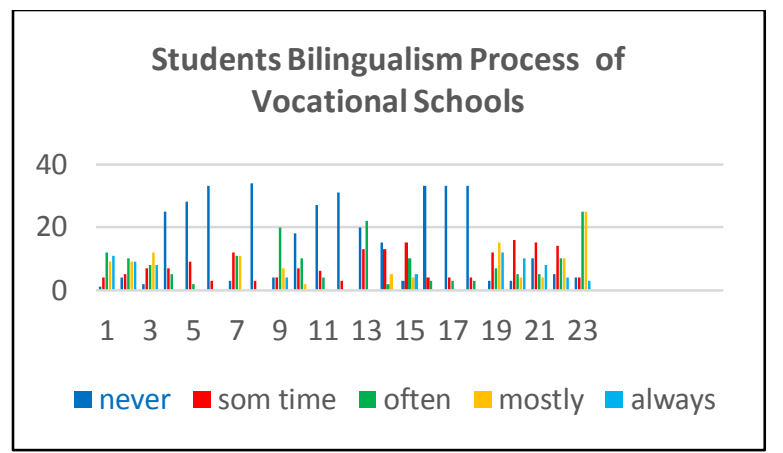

To differentiate the quality of scale, the researcher used five types color for different quality of scoring. Score one symbolize with the color of old blue, score two is represented with the color red, score tree is shown with the green color, purples symbolized score four, and score five is symbolized with light blue. The researcher used twenty three questionnaires in relation with the process of forming bilingualism of vocational schools of Purworejo, central Java, Indonesia. The questioner number one is as the follow: (1) Knowing automotive terms is in serious of learning the components of light vehicles. Based on the answer of this questionnaire, students of vocational schools often learning the automotive terms. It is stated by putting the green color in the highest position in the graphic. Students of vocational schools in Purworejo, Indonesia never learning the automotive terms at the lowest level. It is stated in the graphic by the old blue. The old blue is at the lowest level. Students of vocational schools in Purworejo, Indonesia always learning the automotive terms at the second level. It means that students of vocational schools always learning automotive terms. It is presented in the graphic by using old blue color. Students of vocational schools mostly learning automotive terms are at the third level. This level represented that mostly students of vocational schools try to learn automotive terms seriously. It is presented at the graphic by using purple color. Further, it is limited number students of vocational school sometimes learning automotive terms. The researcher presented it in the graphic using red color. Based on these description, the researcher argued that students of vocational high school in Purworejo, Indonesia have high encouragements to learn automotive terms of light vehicles. Then, the researcher also exploring the types of language used in learning process. (2) Did learning automotive terms using more than one languages?

After analyzing the data taken from the fields of research, it is stated that students of vocational high school in Purworejo, Indonesia often using more than one languages in learning bilingualism of automotive terms. It is presented in the graphic that green color is at the highest level that it is representing students of vocational schools often using more than one languages to produce automotive terms. Students who always using more than one languages when they are learning automotive terms at the second grade. Further, students of vocational schools that sometimes and never using more than one languages in learning automotive terms, it is at the lowest level. It means that students of vocational schools generally used more than one languages to learn automotive terms of light vehicles.

Furthermore, the researcher presented questionnaire concerning with the foreign language that often used in forming automotive terms. The questionnaire is as the follow: (3) the foreign language that often to be used in learning automotive term is English.

Data analyzes presented in the graphic that, green and light blue graphic are in the balance level. It showed that students of vocational school in Purworejo high frequency used English for naming automotive terms. Further, old blue and red representing the use English to name automotive term. It means that view students of vocational school who did not use English to name automotive terms. Other foreign language which is possible to be used to name automotive terms is German.

The questioner is as the follow; (4) other foreign language which is used for learning automotive term is German. Concerning with the using German for learning automotive terms, the data analysis performing as the follow; the old blue graphic is at the highest level. It means that students of vocational school Purworejo, Indonesia mostly never used German as tool for naming automotive terms. Students of vocational school are limited using German for naming automotive terms. It is represented by position of red graphic which is at low level.

The following possible foreign language used for learning automotive terms is Dutch language. To investigate the using of Dutch language by students of vocational school in learning automotive terms, the following researcher used the questionnaire. The questionnaires is as follow; (5) Dutch language is used to learn automotive terms by students of vocational school, Purworejo, Indonesia. The researcher analyzing the data particularly about using Dutch language in learning automotive terms, and the results of data analyzing is as the follow. The graphic of using Dutch language is at the old blue graphic. It means that the Dutch language is mostly never used in learning automotive terms. It is stated that only limited founding about using Dutch language in learning automotive terms. It is represented by graphic of using Dutch language at the red color.

The next assumption is using France for learning automotive terms also investigated by the researcher. Further, the researcher developed the questionnaire concerning with using France in learning automotive terms. The questonnarrie is as the follow: (6) France is 
one of the foreign language to be used for learning automotive terms. The data analysis shows that the graphic of old blue is in the highest level, and it is only limited students of vocational high school Purworejo, Indonesia found automotive terms presented in France. It is stated in the graphic of red color. In this research, the researcher assume that Indonesian language is used for learning automotive terms, to specify the using of Indonesian language for learning automotive terms, the researcher write the following questionnaire. (7) Indonesian language is used for learning light components of vehicles.

Referring to the data analysis particularly about using Indonesian language concerning with learning automotive terms, the graphic is stated as the follow; green graphic is at the highest position level. It means that Indonesian language often used to learn automotive terms. Then the graphic of purple and light blue are at the similar level. It means that many students of vocational school used Indonesian language for learning automotive terms. In this study, the researcher also investigating local languages which are possible to be used for learning automotive terms. Relating with the use of local language, the questionaries' is as follow; (8) Sudanese is one of local language used to learn automotive terms. It is presented in the graphic that Sudanese is never used to learn automotive terms. It means that the students of vocational high school in Purworejo, Indonesia are not the speaker of Sudanese. This explanation presented in the graphic of old blue color which is in the highest level.

Red graphic is symbolized the using of Sudanese in learning automotive terms is limited. Geographically, students of vocational school in Purworejo, Indonesia are Javanese speakers.

Related with the geographic background, the researcher assumed than Javanese are possible to be used to learn automotive terms. Further, the questionaries' about using Javanese as naming automotive terms is as follow; (9) Javanese is used for naming automotive terms by students of vocational, Purworejo, Indonesia. The green graphic is at the highest position. It means that students of vocational school often used Javanese language for learning automotive terms. Graphic of light blue and purple are proving that Javanese is always used in learning automotive terms. Further, red graphic is at the low level, it means that it is limited students of vocational school who did not use Javanese in learning automotive terms.

The researcher assumed that students of vocational high school used other local languages beside Sudanese. The researcher creates the following questionnaire; (10) other local languages are used in learning automotive terms by students of vocational school of Purorejo, Indonesia.
The data analysis stated that, other local languages are not used in learning automotive terms, it is presented in the graphic using old blue color. It is limited number of students of vocational schools use other local languages for learning automotive terms. It is stated in the graphic by red color.

Talking about Javanese language is complicated. It means that Javanese language has some classification, they are Javanese high level, Javanese middle level, and Javanese low level. Javanese low impoliteness is Javanese low level that mostly used by the local Javanese speakers. Javanese language has more than one classification, further in this research, the researcher begin to investigate what kind of Javanese classification used by students of vocational schools, Purworejo, Indonesia. The questionnaire is as the follow; (11) Javanese high level is used by students of vocational schools in learning automotive terms. Based on the data analysis, students of vocational schools never used high level Javanese level for learning automotive terms. It is presented in the graphic of old blue color. The researcher also investigate the using of Javanese middle level for learning automotive terms by students of vocational school. For this purposes, the researcher writes the following questionnaire; (12) Javanese middle level is used by students of vocational school for learning automotive terms. Data analysis stated that students of vocational school are never used Javanese middle level for learning automotive terms. It is stated in the graphic of old blue color. Further red graphic represented that students of vocational high school are limited number to use Javanese middle level for learning automotive terms.

The researcher investigated other possible Javanese level which is used by students of vocational school for learning automotive terms. For this purposes, the researcher write the following questionnaire; (13) Javanese low level is used by students of vocational school for learning automotive terms. Referring to the data analysis, students of vocational school mostly never used Javanese low level for learning automotive terms. It is stated in the graphic that old blue color is at the high level. Further, red graphic color show that students of vocational school are limited to use Javanese high level for learning automotive terms.

Other Javanese level is the lowest un-polite Javanese level. The researcher assumed that, it is possible for students of vocational school used lowest un-polite Javanese level for learning automotive terms. For specific investigating, researcher used the following questionnaire; (14) Lowest impolite Javanese level is used to learn automotive terms by students of vocational schools. Referring to the data analysis, the researcher' presented that graphic of old blue color stated that students of vocational school never used 
lowest un-polite Javanese level for learning automotive terms.

The researcher wants to investigate the using casual Javanese level in this study. The researcher assumed that casual Javanese level used by students of vocational school to learn automotive terms. To investigate this phenomenon, the researcher used the following questionnaire; (15) casual Javanese level is used by students of vocational school to learn automotive terms. Based on the data analysis, it is stated that mostly the students of vocational schools used casual Javanese level for learning automotive terms. It is stated in the red color graphic at the highest level. There are some regency's rounded Purworejo, such as west side are Kebumen and Banyumas. Further, north side are Magelang and Wonosobo, while at the east side is Kulonprogro regency.

Based on this geography, the researcher assumed that the neighbors regencies such as, Kebumen, Banyumas, and Wonosobo have different dialect from Purworejo. Furthermore, the researcher' would like to investigate the possible influences of dialect from Kebumen, Banyumas, and Wonosobo. Concerning with the influences of three neighbor regencies, the researcher' formulate the questionaries' as follow; (16) the Javanese dialect which is used by students of vocational high schools in Purworejo is wonosobo dialect. The graphic of old blue color is at the highest level. It means that students of vocational high school never use wonosobo dialect for learning automotive terms.Based on the graphic, red graphic is at the lowest level. It means that, students of vocational school who used wonosobo dialect is limited.

Not only wonosobo dialect that is possible to be used by students of vocational school for learning automotive terms, it is possible Kebumen dialect also used by students of vocational schools to learn automotive terms. Further, the questionnaire related with using Kebumen dialect is as follow. (17) Kebumen dialect is used by students of vocational school for learning automotive terms. Referring to the data analysis, the researcher presented the graphic of old blue color is at the highest level. It means that students of vocational schools in Purworejo, Indonesia never use Kebumen dialect for learning automotive terms. Not only Kebumen dialect which is possible to influence the process of learning automotive terms but also Banyumas dialect is possible used by students of vocational school to learn automotive terms. Further, the researcher developed the following questionnaire: (18) Banyumas dialect is one of dialect which is used by students of vocational school for learning automotive terms. Based on the data analysis, the researcher stated that students of vocational school never used Banyumas dialect for learning automotive terms. It is presented in the graphic of old blue color that represented the students of vocational high school who did not use it as one of alternative dialect. Further, referring to the use of the three dialects, such as Kebumen, Banyumas, and Wonosobo, it is significantly that no one of these dialect influenced to the process of developing the bilingualism of automotive terms. Then the researcher assumed that students of vocational high school Purworejo, Indonesia used the Purworejo dialect for learning automotive terms. To specify this investigation, the researcher create the following questionnaire; (19) Purworejo dialect is used by students of vocational, Purworejo, Indonesia for learning automotive terms. Referring to the graphic, purple color is at the highest level. It means that students of vocational school Purworejo, Indonesia used their own local dialect for learning automotive terms. (20) Purworejo dialect is different from the language that they used for learning automotive term. Based on the data analysis, the researcher found that graphic of light blue and purple color are at the high level. It means that students of vocational school mostly used Purworejo dialect for learning automotive terms. The graphic of red color is at the high level. It means that students of vocational school are rarely used other languages for learning automotive terms.

The researcher investigating deeply about using Purworejo dialect in the learning process. The researcher assumed that Purworejo dialect used by students of vocational school inside and outside the classes. Concerning about this issue, the researcher developed the following questionnaire; (21) commonly students of vocational school used Purworejo dialect for learning automotive terms. Based on the data analysis, Graphic of purple color stated that commonly students of vocational school always used Purworejo dialect for learning automotive terms. Further, graphic of red color is at low level. It means that it is limited students of vocational school who did not use Purworejo dialect as a tool for learning automotive terms. Further, the researcher investigate of using Purworejo dialect for learning automotive terms in the vocational school. It means that Purworejo dialect is only limited at the school or it is also used in the society freely. For investigating this idea, the researcher writes the following questionnaire; (22) students of vocational school used Purworejo dialect only limited at the school.

Based on the data analysis, the researcher found that graphic of green and purple are at the balance level, it means that student's vocational school used Purworejo dialect specifically. It represented that students of vocational school mostly used Purworejo dialect in the school.

The researcher explored more about using Purworejo dialect, it is particularly investigation, whether Purworejo dialect really used by students of 
vocational school at school and in society or not. To investigate this specific discussion, the researcher presented the following questioners; (23) students of vocational school used Purworejo dialect for learning automotive terms at school and in the society. Referring to results of the data analysis, it is presented in the graphic that purple and green color are at the similar level, it means that students of vocational school used Purworejo dialect for learning automotive terms both at school and in the society with high frequency.

\section{Conclusion}

The researcher concludes that language uses in the learning process is not influenced by other local languages. The language uses in learning process is only influenced by Purworejo dialect. It means that learning process of automotive in Purworejo is effected by Purworejo dialect. Then, tools, components, and engines of vehicles are used English to be recognized by students. The process of language uses in Purworejo should be more universal. Further, the speakers of learning process in Purworejo will be more flexible when they are in other countries. The speakers of language uses in the learning process particularly in Purworejo are better to receive other foreign languages not only English.

\section{Bio Data}

Sudar is lecturer in English Education Study Program, Purworejo Muhammadiyah University, and Central Java, Indonesia. He holds Dr in English Language Education Study of Semarang State University, Indonesia 2014. His research interests focus on language learning and teaching, particularly he is interested in teaching linguistics and Discourse (Discourse Analysis, and Critical Discourse Analysis). rofiqsdr@gmail.com

\section{References}

Ali, Hassan, \&Jousoff.2010. Information Literacy Skills of Engineering Students.IJRAN, University Teknology Malasyia International Campus. Jalan Senmarak 54100, Kuala Lumpus, Malasyia.

Cope and Kalantzis. 2000. Multiliteracies: Literacy Learning and the Design of Social Futures. USA and Canada. Routledge. New York.

Dornyei.2010. Questionnaires in Second Language Research. New York: Lawrence Erlbaum Associates, Ltd.

Faisal.1995. Metode Kualitatif. Jakarta: Rajawali Press.

Hammond. 1992. English for Social Purposes. A Hand Book for Teachers of Adult Literacy. National Centre for English Language Teaching and Research. Macquarie University, Press. Sydney NSW 2109.

Husein, Umar. (1999). Sumber Daya Manusia dan Organisasi. Jakarta: Gramedia.

Kern.2000. Literacy and Language Teaching. Oxford University Press. Oxford. New York.

Miles \&Huberman.1992. Qualitative Data Analysis- An expanded Source Book, 2nd edition, London: Sage Publications.

Messer,Kelly, \&Poirir. 2005. Engineering Information Literacy and Communication. Proceeding of the Twelft International Conferece on Learning. Canada.d.messer@qut.edu.au.

Owen\&Schwenger.2008. Increasing Student success through effective literacy and numeracy Support. Paper Presented at the Teaching and Learning Conference. Eastern Institutes of Technology, Hawkes, Bay.

White, Breslow \&Hasting.2015. Exploring Literacy as a Global Competency: An International Study of the Teaching and Learning of Communication. Proceeding of 2015 International Conference on Interactive Collaborative Learning (ICL). 9781 - $\quad 4799-1 / 15 / \$ 31.00 \quad .2015$ Italy 